\title{
Donor-specific anti-HLA antibodies detection by de facto crossmatch method in pediatric recipients before haploidentical hemato- poetic stem cell transplantation
}

\author{
Olesya V. Paina ${ }^{1}$, Irina E. Pavlovaa ${ }^{1,2}$, Natalia E. Ivanova ${ }^{1}$, Alexander L. Alyanskiy ${ }^{1}$, Tatiana A. Bykova ${ }^{1}$, \\ Ludmila S. Zubarovskaya ${ }^{1}$, Alexander D. Kulagin ${ }^{1}$, Boris V. Afanasyev ${ }^{1}$ \\ ${ }^{1}$ RM Gorbacheva Research Institute of Pediatric Oncology, Hematology and Transplantation, Pavlov University, St. Petersburg, \\ Russia \\ ${ }^{2}$ Russian Research Institute of Hematology and Transfusiology, St. Petersburg, Russia
}

Dr. Irina E. Pavlova, Russian Research Institute of Hematology and Transfusiology, $2^{\text {nd }}$ Sovetskaya St 16, 191024, St. Petersburg, Russia
Phone: +7 (921) 9836664

E-mail: dr_pavlova_irina@mail.ru

Citation: Paina OV, Pavlova IE, Ivanova NE et al. Donor-specific anti-HLA antibodies detection by de facto crossmatch method in pediatric recipients before haploidentical hematopoetic stem cell transplantation. Cell Ther Transplant 2020; 9(4): 53-58.

\section{Summary}

Donor-specific antibodies (DSA) have been recently recognized as an important risk factor for the failing engraftment of HLA-haploidentical donor cells. In this study, we aimed to determine the frequency of anti-HLA DSA detection in recipients before haplo-HSCT using the enzyme-linked immunosorbent assay and establishing an association between the DSA presence and primary graft failure and/or graft hypofunction in children after haplo-HSCT. 40 patients have been tested (22-M, 18-F): 27 ALL, 8 AML, 1 MDS, 1 AA, 3 JMML. The median age of the patients was 8.5 years ( $1-17$ years). Medians of the number of transplanted nucleated and CD34+ cells were $8.5 \times 10^{8} / \mathrm{kg}\left(2.3-17.9 \times 10^{8} / \mathrm{kg}\right)$ and $7.6 \times 10^{6} / \mathrm{kg}$ $\left(2.3-8.2 \times 10^{6} / \mathrm{kg}\right)$ respectively. The donor bone marrow was the source of stem cells in all cases. Detection of DSA has been performed by using the commercial kit (XMatch $^{\circledast}$, Protrans) that allows determining antibodies against donor's HLA class I and class II separately in the ELISA de facto crossmatching. Among all the examined children, 3 patients $(7.5 \%)$ were found to be positive for DSA, while the vast majority $(n=37 ; 92.5 \%)$ had no detectable DSA. It was also found that in all cases DSA were directed against HLA class II antigens.
Comparative analysis of the results shows that patients with DSA before haplo-HSCT are more likely to develop primary graft failure or hypofunction compared to the group of recipients without DSA. All 3 patients with detected antibodies were diagnosed with either primary graft failure $(n=1,33 \%)$ or graft hypofunction $(n=2$, $67 \%)$. In the control group of patients without DSA primary graft failure or graft hypofunction were observed in $5(13.5 \%)$ and $1(2.7 \%)$ cases respectively, with a total of 6 cases (16.2\%). Implementation of DSA-testing into routine practice in recipients before haplo-HSCT will optimize the choice of a donor, as well as select a group of potential recipients who need to be treated in the pre-transplant period for desensitization.

\section{Keywords}

Donor-specific antibodies, hematopoietic stem cell transplantation, HLA-haplocompatible donors, HLAhaploidentical donors. 


\section{Introduction}

Hematopoietic stem cell transplantation (HSCT) from haploidentical donors (haplo-HSCT) increasingly becomes the method of choice in the treatment of patients with hemoblastoses and hematopoietic depressions. HLA-matched related donors are often not available, and there is no sufficient time for searching unrelated donors, or matched unrelated donors cannot be found neither in the domestic nor in foreign bone marrow registers. New conditioning regimens implementation, improvement of graft processing technologies, as well as the use of effective methods of graft-versushost disease (GvHD) prevention significantly reduced the risk of severe complications and allowed to expand the indications for such a kind of transplantations [1, 2]. Thus, indication of cyclophosphamide following haplo-HSCT for the GvHD-prevention and selective $\alpha \beta$-depletion of T-cells from a graft significantly increased patient survival rates [2, $3,4,5]$.

HLA-haploidentical donor may be available for the most of patients: first- and second-line relatives who inherit the same HLA-haplotype as the patient may be related HLA-haplocompatible, or even HLA-haploidentical donors. According to Fuchs [6] the related HLA-haploidentical donor in pediatric practice can be found for more than $95 \%$ of patients, and the average number of haploidentical donors for one patient can be two or more. Such donors are usually available and motivated to donate. But haplocompatible/haploidentical donors are just partially compatible with the patient's HLA-antigens. If the patient develops antibodies against HLA-antigens of its donor's cells, i.e., the donor-specific antibodies (DSA), these DSA may potentially cause the immunomediated haplo-HSCT complications. Primary graft failure is the most dangerous hazard. Ciurea et al. have found DSA in 18\% (22 out of 122) of patients before haplo-HSCT. In the group of patients with DSA, the frequency of primary graft failure was significantly higher (32\%) than in patients without DSA $(4 \%)(p<0.001)$ [7]. Chang et al. found DSA in $11.3 \%$ of patients (39 out of 345 ) for whom then haplo-HSCT has been performed [8]. With DSA levels of more than 2000 units, the incidence of primary graft failure was significantly higher $(23.7 \%)$ than at their absence, and DSA levels of less than 2000 units $(1.9 \%)(\mathrm{p}=0.003)$. Due to primary graft failure, the survival rate is significantly lower in patients with DSA after haplo-HSCT [9].

The aim of the current study was to determine frequency of anti-HLA DSA detection in recipients before haplo-HSCT using the enzyme-linked immunosorbent assay (ELISA) and to prove an association between the DSA presence and risk of primary graft failure and (or) graft hypofunction in children after haplo-HSCT.

\section{Materials and methods}

Current publication presents the results of a pilot retrospective single-center study. Forty pediatric patients who received haplo-HSCT with unmanipulated graft have been included into the study. The study proceeded in the clinic of R. M. Gorbacheva Memorial Research Institute for Pediatric Oncology, Hematology and Transplantation over the period from July 2019 to March 2020. HLA-typing of recipients and their donors was performed with molecular-genetic methods. If based on the results of HLA-typing (HLA-A, $\mathrm{B}, \mathrm{C}, \mathrm{DRB} 1, \mathrm{DQB} 1$ ) in the patient and first-line relatives at low-resolution level, it was possible to establish four family haplotypes, then the recipient and the donor, matched by one of these haplotypes were considered as haploidentical. If the family study did not allow to determine four haplotypes, then the high-resolution HLA-typing has been performed by Sanger sequencing. The recipient/donor concordance for, at least, 5 alleles out of 10 was considered haplo-compatible. However, in vast majority of patients (95\%), haploidentity could not be determined, so we considered haplo-compatible all the performed HSCTs. Demographics and clinical characteristics of the patients are presented in Table 1.

\section{Table 1. Demographic and clinical characteristics of the patients}

\begin{tabular}{|l|l|}
\hline Characteristics & Values \\
\hline Number of patients, $\mathrm{n}$ & 40 \\
\hline Age, median (range), years & $8.5(1-17)$ \\
\hline $\begin{array}{l}\text { Sex, n (\%) } \\
\text { Male }\end{array}$ & $22(55)$ \\
Female & $18(45)$ \\
\hline Diagnoses, n (\%) & \\
AML & $8(20)$ \\
ALL & $27(67.5)$ \\
MDS & $1(2.5)$ \\
AA & $1(2.5)$ \\
JMML & $3(7.5)$ \\
\hline Time, "diagnosis - HSCT", & $10(5-60)$ \\
median (range), months & \\
\hline
\end{tabular}

Note: $A M L$, acute myeloid leukemia; ALL, acute lymphoblastic leukemia; MDS, myelodysplastic syndrome; AA, aplastic anemia; JMML, juvenile myelomonocytic leukemia.

The median age of patients at the time of HSCT was 8 (1$17)$ years. The cohort was dominated by patients with ALL $(67.5 \%)$ and AML (20\%). Medians of the number of transplanted nucleated and CD34+ cells were $8.5 \times 10^{8} / \mathrm{kg}(2.3-$ $\left.17.9 \times 10^{8} / \mathrm{kg}\right)$ and $7.6 \times 10^{6} / \mathrm{kg}\left(2.3-8.2 \times 10^{6} / \mathrm{kg}\right)$, respectively. Stimulated, unmanipulated bone marrow was a source of CD34+ cells in all cases. The donor's hematopoesis was stimulated by G-CSF at the dose of $5 \mathrm{mcg} / \mathrm{kg} /$ day during 3 days, and the bone marrow myeloexfusion has been performed on the $4^{\text {th }}$ day. 26 recipients $(65 \%)$ received myeloablative conditioning (MAC) based on busulfan at a total dose of $12 \mathrm{mg} / \mathrm{kg}$ and fludarabine $\left(150 \mathrm{mg} / \mathrm{m}^{2}\right)$. The reduced-intensity conditioning (RIC) has been received by 14 (35\%) of patients, i.e.,: melphalan at the total dose of $140 \mathrm{mg} / \mathrm{m}^{2}$ and fludarabine $\left(150 \mathrm{mg} / \mathrm{m}^{2}\right)$. Post-transplant cyclophosphamide at the days +3 and +4 post-HSCT was administered at the dose of $50 \mathrm{mg} / \mathrm{kg}$ per day, calcineurin inhibitor tacrolimus $(0.03 \mathrm{mg} / \mathrm{kg} /$ day with a target concentration of $3-5 \mathrm{ng} / \mathrm{ml})$, and mTOR inhibitor - sirolimus $\left(1 \mathrm{mg} / \mathrm{m}^{2} /\right.$ day, with a target concentration of 3-5 ng/ml) were used to prevent acute GvHD. The distribution of HLA-haploidentical donors was as follows: fathers, 24 cases; mothers, 14 cases; siblings, in 2 cases. 
The primary graft failure criterion was considered as failure to reach the level of neutrophils of more than $0.5 \times 10^{9} / 1$ within three consequent days +35 to 42 posttransplant. The hypofunction of the transplant was diagnosed as two- or three-lineage cytopenia $\left(\mathrm{Hb}<100 \mathrm{~g} / \mathrm{l}\right.$, neutrophils $<0.5 \times 10^{9} / \mathrm{l}$, platelets $<10^{9} / \mathrm{l}$ ), regardless of the time post-transplant, requirements for blood transfusion, and hypocellular bone marrow in presence of complete donor chimerism and absence of acute GvHD, or a disease relapse.

All the patients were examined for the presence of anti-HLA DSA before haplo-HSCT. The laboratory method selected for DSA detection was an enzyme immunoassay analysis (XMatch ${ }^{\oplus}$, PROTRANS, Germany). From the donor blood samples lymphocytes were isolated and then lysed. The cell lysates containing donor HLA-molecules were then incubated with capture antibodies precipitated at the bottom of ELISA-wells separately for HLA class I and II (Fig. 1).

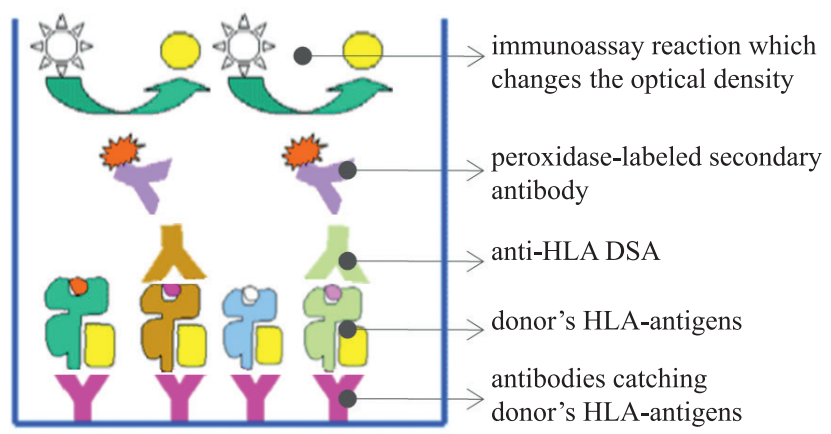

\section{Figure 1. Enzyme Immunoassay in the presence of DSA to HLA-antigens of the donor}

The donor's native HLA-antigens were bound to the capturing antibodies fixed to the bottom of the wells. Then the patient's blood serum samples were incubated at this carrier. In the case of DSA presence, these antibodies were attached to the donor's HLA-antigens. After series of washings from unbound antibodies, secondary antibodies labeled with horseradish peroxidase were added. These antibodies could only bind to DSA previously fixed to the donor's HLA-antigens. To visualize the results, a peroxidase-oxidized substrate was added to change the color of the solution. Optical density of the reaction products was measured by using an enzyme immunoassay analyzer (Immunochem-2100, High Technology Inc, USA) at wavelengths of 450 and $620 \mathrm{~nm}$. The result was accepted as valid if the optical density in positive control was $\geq 0.350$ OD and in negative control $\leq 0.150$ OD. The result was considered positive, if the optical density was at least twice higher than negative control.

We have used ELISA-based crossmatch to detect DSA de facto opposite to virtual crossmatching based on the analysis of Luminex results. The idea was to prove the direct interaction between HLA-antigens of the certain donor with antibodies of the patient. ELISA was also the method of choice since it allowed to avoid false-positive results that occur in CDC or FC-XM due to therapiutic monoclonal antibodies received by the patients before haplo-HSCT. Thus, the chosen method could provide the direct interaction evidence, and could be used qualitatively.
The differences in the frequency of primary graft failure and graft hypofunction between the analyzed groups were evaluated by means of the two-tailed Fisher's exact test. For statistical data processing, STATISTICA 8 software was used (StatSoft Inc., USA).

\section{Results}

Among all the examined children, three patients (7.5\%) were found to be DSA-positive, while the vast majority $(n=37$; 92.5\%) had no DSA. It was also found that, in all cases, DSA were directed against HLA class II antigens.

Brief description of patients with DSA is as follows:

1) Patient K.P., 10 years old; acquired idiopathic aplastic anemia, severe form; duration of the disease before haplo-HSCT was 5 years; previous history of multiple hemotransfusions.

2) Patient I.V., 15 years old; acute myeloblastic leukemia with interstitial $7 p$ and 9q deletions; high risk group; allogeneic unrelated bone marrow transplantation (28.04.2018); engraftment by the day +20 ; donor lymphocyte infusion (DLI, $\mathrm{n}=5$ ); isolated bone marrow relapse (of 11.02.2019); transplant rejection (25.03.2019); a history of multiple hemotransfusions; duration of the disease prior to haplo-HSCT was 1.5 years.

3) Patient K.P., 14 years old; acute myeloblastic leukemia (FAB M4) with co-expression of CD7, CD79A; NUP98 gene rearrangement; therapy according to the AML-BFM 2004 Protocol; the first early isolated bone marrow relapse documented at 07.03.2019 with resistance to therapy; duration of the disease from diagnosis to haplo-HSCT was 9 months.

When analyzing efficiency of performed haplo-HSCTs, we have found that nine patients $(22.5 \%)$ had either primary graft failure $(n=6 ; 15 \%)$ or graft hypofunction $(n=3 ; 7.5 \%)$.

Primary graft failure and allograft hypofunction, being a sign of poor engraftment in these patients, required then a repeated allo-HSCT from other donor. Of note, the improved analytic technologies for evaluating donor chimerism have shown that some patients can develop graft hypofunction even when the complete donor chimerism is observed.

Comparative analysis of the results shows that patients with DSA prior to haplo-HSCT are more likely to develop primary graft failure, or hypofunction compared to the group of recipients without DSA. All three patients with detected antibodies were diagnosed with either primary graft failure $(n=1 ; 33 \%)$ or graft hypofunction $(n=2 ; 67 \%)$. In the control group of patients without DSA, primary graft failure or graft hypofunction were observed in $5(13.5 \%)$ and $1(2.7 \%)$ cases respectively, with a total of 6 cases $(16.2 \%)$ (Table 2$)$.

\section{Discussion}

The role of DSA in hematopoietic cell transplantation remained unclear for a long time. For allogeneic HSCT, clinicians tried to search for either HLA-identical related, or HLA-matched unrelated donors, in these cases DSA to HLA-antigens would not develop in principle. Therefore, when studying graft failure mechanisms, the cellular immunity has drawn much attention. Nowadays, its generally 
Table 2. Frequency of primary graft failure and graft hypofunction depending on the presence of DSA $(n=40)$

\begin{tabular}{|l|l|l|l|}
\hline Clinical case & DSA(+), $\mathbf{n}(\%)$ & DSA(-), $\mathbf{n}(\%)$ & $\mathbf{p}$ \\
\hline Primary graft failure & $1(33.33 \%)$ & $5(13.51 \%)$ & 0.3943 \\
\hline Graft hypofunction & $2(66.67 \%)$ & $1(2.7 \%)$ & 0.0113 \\
\hline Total & $3(100 \%)$ & $6(16.22 \%)$ & 0.0085 \\
\hline
\end{tabular}

accepted that, following organ and tissue transplantation, the immune system reacts to the HLA-antigens differing from recipient HLA-antigens by the mechanisms of both cellular and humoral immune response. At the same time, it would be noted that the exact mechanism by which DSA causes graft failure in haplo-HSCT, remains undetermined.

The impact of DSA to the outcome of organ transplantation became the point for some studies on their role in haplo-HSCT. The results of these works represented the basis of clinical recommendations aimed for identification and elimination of DSA in patients before haplo-HSCT, published by the European Society for Blood and Marrow Transplantation (EBMT) in 2018 [10]. In adult patients with hemoblastosis requiring allo-HSCT, the detection frequency of anti-HLA antibodies may reach $40 \%,[11,12,13]$. However, not all of these anti-HLA antibodies are directed against donor HLA-antigens. Using highly sensitive methods of solid-phase analysis, it was detected that anti-HLA antibodies were donor-specific in $24 \%$ of haplo-HSCT recipients [14]. According to the most researchers, the prevalence of DSA varies from $10 \%$ to $21 \%$ [9]. In the present study, we were able to identify DSA only in $7.5 \%$ of examined patients. Probably, the lower rate in children is observed due to anti-HLA antibodies arising after hemotransfusions and, in some cases, following previous HSCT from a partially matched donor. Among adults, HLA-allosensitization is most often detected in women (up to $86 \%$, against $5 \%$ in men), with pregnancy being the most common reason.

Our data on the high frequency of primary graft failure and/or graft hypofunction in the recipient group with the presence of DSA (100\%), compared to the group, in which DSA is not detectable (16.22\%) agreed with previous data [9] about the influence of DSA upon the outcome of haplo-HSCT. However, due to minority of patients with identified DSA, one should continue this study in order to confirm these results in a more representative sample.

It is recommended to determine DSAs in all patients 1 month before haplo-HSCT. When DSA are detected, a search for alternative haplo-compatible donor should be considered. If such donors are not available, it is necessary to use the treatment reducing the DSA-levels and to prevent the development of new anti-HLA DSA. Laboratory monitoring of DSA would be used as a way to assess effectiveness of treatment, and should be performed just before transplantation and every week after it [10].

\section{Conclusion}

The method we used to determine DSA is sufficiently informative, has a number of advantages over the serological method using a lymphocytotoxic test, flow cytometry, as well as multiplex analysis methods, and it does not require intact donor lymphocytes incubated immediately with DSA. The test does not give false positive results in the presence of any non-anti-HLA IgG's in the patient's serum that can contact the membrane and activate the complement. HLA-molecules of a real donor as an antigen material are used for the test. Results are recorded automatically. It is necessary to perform a comparative study of the results of DSA testing using enzyme immunoassay with a multiplex analysis which is more common method in routine practice, using the $\mathrm{Lu}$ minex platform. Implementation of DSA-testing for the routine practice in recipients prior to haplo-HSCT will optimize the choice of a donor, as well as to select a group of potential recipients who requires desensitization treatment over the pre-transplant period.

\section{Conflict of interest}

None declared.

\section{References}

1. Afanasyev BV, Zubarovskaya LS, Alyanskiy AL, et al. The donor choice for allogeneic stem cell transplantation. Russian Journal of Children Hematology and Oncology. 2016; 3(3): 30-36 (In Russian).

2. Maschan MA. T-lymphocytes alpha/beta depletion - reliable platform for the development of stem cell transplantaion from haploidentical donors. Russian Journal of Children Hematology and Oncology. 2015; 2 (3):34-38. (In Russian).

3. Paina OV, Stancheva NV, Semenova EV, et al. Haploidentical transplantation of hematopoetic stem cells in treatment of children and adolescents with resistant forms of acute leucosis. Russian Journal of Children Hematology and Oncology. 2015; 2(3):39-45 (In Russian).

4. Paina OV, Kojokar' PV, Borovkova AS, et al. Results of alogeneic stem cell transplantation from haploidentical donor with unmanipulated bone marrowtransplant in children and adolescents with acute leucosis from high risk group: 10 years experience. Issues in Hematology/Oncology and Immunology in Pediatrics. 2018; 17(2): 21-27 (In Russian).

5. Lee CJ, Savani BN, Mohty M, Labopin M, Ruggeri A et al. Haploidentical hematopoietic cell transplantation for adult acute myeloid leukemia: a position statement from the Acute Leukemia Working Party of the European Society for Blood and Marrow Transplantation. Haematologica. 2017; 102(11);1810-1822. 
6. Fuchs EJ. Haploidentical transplantation for hematologic malignancies: where do we stand? Hematol. Am.Soc.Hematol.Educ.Program. 2012; 2012: 230-236.

7. Ciurea SO, Mulanovich V, Jiang Y, et al. Lymphocyte recovery predicts outcomes in cord blood and T cell-depleted haploidentical stem cell transplantation. Biol Blood Marrow Transplant. 2011;17:1169-1175.

8. Chang YJ, Zhao XY, Xu LP, Zhang XH, Wang Y, Han W, et al. Donor-specific anti-human leukocyte antigen antibodies were associated with primary graft failure after unmanipulated haploidentical blood and marrow transplantation: a prospective study with randomly assigned training and validation sets. J Hematol Oncol. 2015; 8:84.

9. Ciurea SO, Thall PF, Milton DR, Barnes TH, Kongtim P, Carmazzi Y, et al. Complement-binding donor-specific anti-HLA antibodies and risk of primary graft failure in hematopoietic stem cell transplantation. Biol Blood Marrow Transplant. 2015;21:1392-1398.

10. The European Society for Blood and Marrow Transplantation (EBMT) Consensus Guidelines for the detection and treatment of donor specific anti-HLA antibodies (DSA) in haploidentical hematopoietic cell transplantation. Bone Marrow Transplantation. 2018; 53: 521-534.

11. Yoshihara S, Maruya E, Taniguchi K, Kaida K, Kato R, Inoue $\mathrm{T}$, et al. Risk and prevention of graft failure in patients with preexisting donor-specific HLA antibodies undergoing unmanipulated haploidentical SCT. Bone Marrow Transplant. 2012; 47:508-515.

12. Chang YJ, Zhao XY, Xu LP, Zhang XH, Wang Y, Han W, et al. Donor-specific anti-human leukocyte antigen antibodies were associated with primary graft failure after unmanipulated haploidentical blood and marrow transplantation: a prospective study with randomly assigned training and validation sets. J Hematol Oncol. 2015; 8:84.

13. Ruggeri A, Rocha V, Masson E, Labopin M, Cunha R, Absi L, et al. Impact of donor-specific anti-HLA antibodies on graft failure and survival after reduced intensity conditioning-unrelated cord blood transplantation: a Eurocord, Societe Francophone d'Histocompatibilite et d'Immunogenetique (SFHI) and Societe Francaise de Greffe de Moelle et de Therapie Cellulaire (SFGM-TC) analysis. Haematologica. 2013; 98:1154-1160.

14. Gladstone DE, Zachary AA, Fuchs EJ, Luznik L, Kasamon YL, King KE, et al. Partially mismatched transplantation and human leukocyte antigen donor-specific antibodies. Biol Blood Marrow Transplant. 2013;19:647-652. 


\title{
Выявление донор-специфических анти-HLA-антител методом индивидуальной перекрестной пробы де-факто у педиатрических реципиентов перед трансплантацией гемопоэтических стволовых клеток от гаплосовместимого донора
}

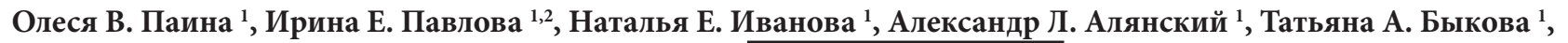 \\ Людмила С. Зубаровская ${ }^{1}$, Александр Д. Кулагин ${ }^{1}$, Борис В. Афанасьев ${ }^{1}$ \\ ${ }^{1}$ НИИ детской онкологии, гематологии и трансплантологии им. Р. М. Горбачевой, Первый Санкт-Петербургский \\ государственный медицинский университет им. акад. И. П. Павлова, Санкт-Петербург, Россия \\ ${ }^{2}$ Российский научно-исследовательский институт гематологии и трансфузиологии Федерального медико- \\ биологического агентства, Санкт-Петербург, Россия
}

\section{Резюме}

Донор-специфические анти-HLA антитела (ДСА) могут являться важным фактором риска недостаточного приживления HLA-гаплосовместимых донорских гемопоэтических клеток (ГСК). Цель настоящего исследования - определить частоту выявления донор-специфических анти-HLA антител у реципиентов перед проведением гаплосовместимой трансплантации ГСК (ТГСК) с помощью метода иммуноферментного анализа и установить взаимосвязь наличия ДСА с первичным неприживлением трансплантата и (или) гипофункцией трансплантата у детей, перенесших ГТГСК.

В работе представлены результаты пилотного ретроспективного одноцентрового исследования. Обследованы 40 пациентов детского возраста, медиана возраста составила 8,5 лет (1 год - 17 лет), которым были выполнены гаплосовместимые трансплантации неманипулированных ГСК в клинике НИИ детской онкологии, гематологии и трансплантологии им. Р.М. Горбачевой (22-M, 18-ж): 27 ALL, 8 AML, $1 \mathrm{MDS}, 1 \mathrm{AA}, 3 \mathrm{JMML}$. Средний возраст пациентов составил 8,5 лет (1-17 лет). Медианы общего числа трансплантированных ядросодержащих и CD34+ клеток составляли $8,5 \times 10^{8} /$ кг $\left(2,3-17,9 \times 10^{8} /\right.$ кг $)$ и $7,6 \times 10^{6} /$ кг $\left(2,3-8,2 \times 10^{6} /\right.$ кг) соответственно. Во всех случаях источником CD34+ клеток был стимулированный неманипулированный костный мозг. Определение ДСА в сыворотке крови реципиентов выполнено с использованием коммерческого набора (XMatch ${ }^{\circledR}$, Protrans), который позволяет определять антитела против донорских антигенов HLA- класса I и класса II отдельно в перекрестном сопоставлении ELISA de facto.
Среди всех обследованных детей у 3-х пациентов (7,5\%) выявлены ДСА, в то время как у подавляющего большинства $(n=37 ; 92,5 \%)$ ДСА не было, во всех случаях ДСА были направлены против антигенов HLA класса II. Сравнительный анализ результатов показывает, что у пациентов с наличием ДСА до гаплосовместимой ТГСК более вероятно развитие первичной недостаточности трансплантата или гипофункции по сравнению с группой реципиентов без DSA. У всех 3 пациентов (100\%) с обнаруженными антителами была диагностирована либо первичная недостаточность трансплантата $(n=1,33 \%)$, либо гипофункция трансплантата $(\mathrm{n}=2,67 \%)$. В группе пациентов без ДСА первичная недостаточность трансплантата или гипофункция трансплантата наблюдались в $5(13,5 \%)$ и $1(2,7 \%)$ случаях соответственно, всего в 6 случаях (16,2\%). Внедрение DSA-тестирования в рутинную практику у реципиентов перед гапло-ТГСК оптимизирует выбор донора, а также выберет группу потенциальных реципиентов, которым необходимо пройти курс лечения в предтрансплантационный период для десенсибилизации.

\section{Ключевые слова}

Донор-специфические антитела, трансплантация гемопоэтических стволовых клеток, HLA-гаплосовместимые доноры, HLA-гаплоидентичные доноры. 